\title{
NOT “JUST A PETROGRAPHER": THE LIFE AND WORK OF FELIX CHAYES (1916-1993)
}

\author{
RICHARD J. HOWARTH \\ Department of Earth Sciences, University College London, \\ Gower Street, London WC1E 6BT, UK \\ r.howarth@ucl.ac.uk
}

\begin{abstract}
Felix Chayes's life and career, largely spent at the Geophysical Laboratory of the Carnegie Institution, Washington, DC, are described. His principal motivation was to improve the reliability of geological interpretation and decision-making through the use of quantitative techniques and the application of statistical methods: e.g., as discussed in his monograph Petrographic Modal Analysis (1956b). He attempted to raise the awareness of the geological community concerning the inherent problems connected with the interpretation of percentaged- and ratio-data, in both petrography and geochemistry, and to develop approaches to their solution (as discussed in his monograph Ratio Correlation, 1971a), although these were never wholly successful. From the mid-1960s onwards, he was deeply involved in the development and application of geochemical databases for igneous petrology (International Geological Correlation Programme-IGCP-Projects 163 and 239). From 1984 he was Chair of the International Union of Geological Sciences (IUGS) Subcommission on Electronic Databases for Petrology. Emphasis is placed on Chayes's early research as this established the motivation for his statistical approach to petrology.
\end{abstract}

\section{INTRODUCTION}

Felix Chayes (1916-1993) always liked to think of himself as a petrographer, but was considered by many to be a petrologist ${ }^{1}$ and a pioneering mathematical geologist. There can be few geological professionals whose career was, like Chayes's, rooted in a liberal arts degree. But, having taken a course in geology as one of his first degree subjects, he subsequently changed direction, completing both an M.A. and a Ph.D. degree in geology in two years each. The greater part of his career was spent at the Geophysical Laboratory of the Carnegie Institution of Washington. His initial research was mainly related to the petrography and genesis of granites, but from the 1950s onwards, his interests turned increasingly to the application of statistical methods to solution of geological problems. The account which follows begins with an outline of his family background, his education, and early career. Then follows discussion of petrological and statistical aspects of his research and finally, his involvement with the development of international petrological databases. Since many of these related activities overlap in time, it has not always been possible to maintain a strictly chronological order. Because of constraints on space, and as his later work tends to be more familiar to the mathematical geology community, particular attention is paid here to an examination of the probable influences which established the direction for much of his subsequent research. Only a selective bibliography of his publications is included.

Chayes was born in a New York hospital on 10 May 1916. He was the second of the three children of Hilda (neé Hoffman) and her husband, Nathan

\footnotetext{
${ }^{1}$ A petrographer is one who studies the mineralogical and textural relationships within rocks, especially as revealed by their study in thin-section, whereas a petrologist is one who studies the occurrence, structure, and history of the origin and mode of formation of rocks. However Chayes may have viewed himself, his work certainly spanned the range of activities normally thought of as 'petrology'.
} 


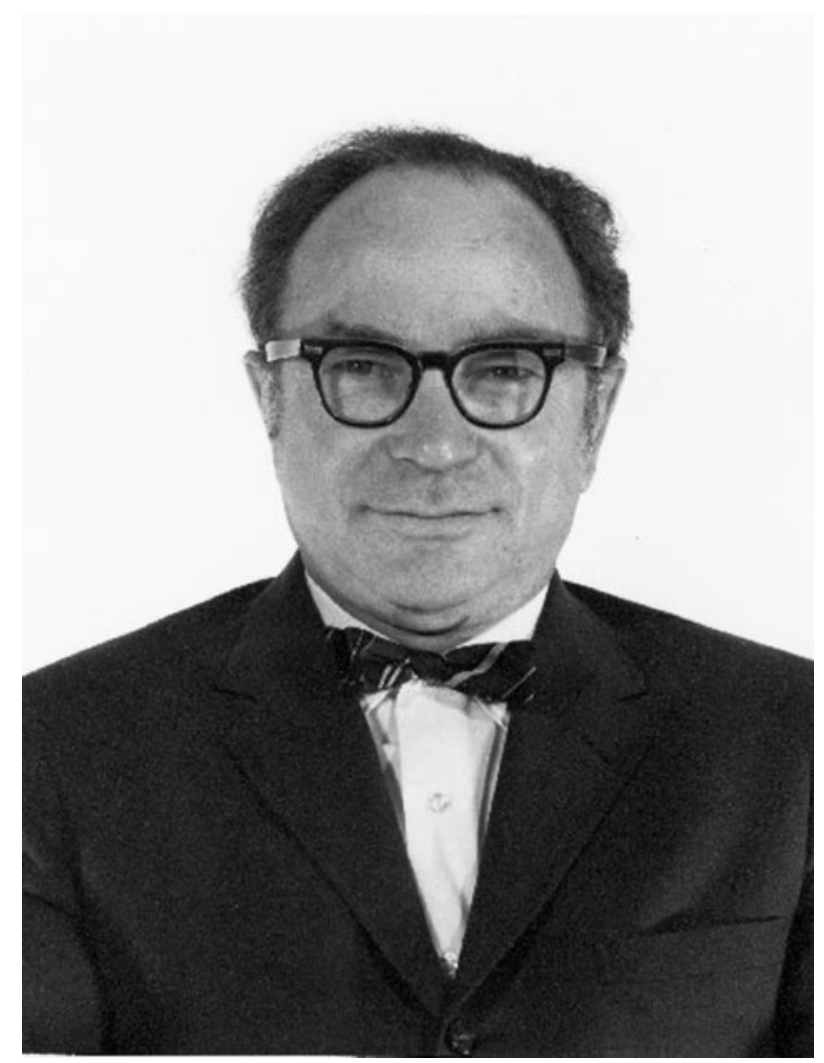

Figure 1. Felix Chayes in 1970. Reproduced with permisssion of the Geophysical Laboratory, Carnegie Institution of Washington.

Chayes. His father established and owned the Chayes Dental Instrument Company, engaged in the manufacture of precision dental instruments and which developed the first high-speed dental handpiece. His mother was a graduate of Hunter College, New York, established to provide higher education for women. She was a member of the first class to be qualified to teach in the public schools of the city of New York, which she did prior to her marriage. Chayes's older brother, Aaron Herbert (1915-1983), inherited the family business. His sister, Natalie (now the widow of Ashton M. Tenney) was born in 1920. The family moved to New Rochelle, one of the commuting suburbs of New York, in Westchester County, in the 1920s. Although the family business went through a hard time in the Depression, it prospered during World War II and was later bought out by a larger company. ${ }^{2}$

As a person, Chayes (Figure 1) was known for his erudition, culture, the

${ }^{2}$ N. C. Tenney (personal communication, 2004). Details of Chayes's family background, personality, and early career are primarily based on personal recollections of his widow, Dr. Irene H. Chayes and his sister, Mrs. Natalie C. Tenney, together with information in: E. H. Timothy Whitten, Ninth William Christian Krumbein Medallist: Felix Chayes, Mathematical Geology, 1986, 18:263-266; Hatten S. Yoder, Jr., Felix Chayes 1916-1993, Spectra [Newsletter of the Carnegie Institution], 1993 (June), 14; E. H. Timothy Whitten, Memorial to Felix Chayes, Mathematical Geology, 1994, 26:157-160; Michael J. Le Bas, Memorial to Felix Chayes, 1916-1993, Geological Society of America Memorials, 1995, 25:27-30; and Harald S. Poelchau, Vera Pawlowsky, and Thomas Jones, Interview: Dr. Irene H. Chayes, IAMG Newsletter, 1998, no. 57 (November), 7. 
clarity of his writing, and his high professional standards. However, his warm disposition, innate kindness, and generosity could be masked by a somewhat reserved manner; his absorption in his work resulted in a lack of awareness in personal dealings, which some perceived as insensitivity ${ }^{3}$ - some of his referee's comments on manuscripts are known to have upset their recipients. ${ }^{4} \mathrm{He}$ played the recorder for relaxation and belonged to the American and Washington recorder societies.

Chayes enrolled as a Batchelor of Arts student at New York University (NYU) in 1932, commuting daily to its coeducational Washington Square College. ${ }^{5} \mathrm{He}$ enrolled in law school and was briefly interested in legal history. Deciding that a career in law was not for him, he then majored in geology, but also gained much from history and literature courses, including taking one on the modern novel. In later years, he took pleasure in recalling characters and episodes from the works of Mann, Proust, Joyce, and Kafka, which he had encountered on this course. Indeed, he met his future wife, Irene Hendry, ${ }^{6}$ in the Washington Square office of one of the undergraduate publications, where she was turning in a review of a collection of prose pieces by the novelist D. H. Lawrence and, by chance, Felix was submitting an essay which he had written on Lawrence's controversial political views. ${ }^{7}$

In 1936, Chayes was awarded his B.A. degree and elected to the Phi Beta Kappa academic honour society. He next enrolled to study for a Master's degree in geology at Columbia University, New York. It was here that he came under the influence of the Scottish petrologist and economic geologist, Samuel James Shand (1882-1957).

Born in Edinburgh, Shand's career had begun at the University of Aberdeen, Scotland, but in 1937, following many years at the University of Stellenbosch, South Africa, where he had studied alkalic massifs, Shand was appointed to the Chair of petrology at Columbia. He was keenly interested in the classification of rocks based on their degree of silica saturation, as reflected in their mineralogy, and the principles of his classification system were first discussed in his textbook Eruptive Rocks (1927). He was also known for his research on the petrogenesis of alkaline igneous rocks. ${ }^{8}$ Shand was responsible for Chayes taking up the study of the alkaline and associated intrusives of the Bancroft area, Ontario, Canada, for both his Master's and Doctoral theses (Chayes 1939a, 1939b,1942a). Chayes was awarded his M.A. in 1939 and gave an oral presentation on his work at the December 1939 meeting of the Geological Society of America. ${ }^{9}$ He was awarded a fellowship at Columbia for the 1940/41 academic years to undertake research for his Ph.D. His dissertation was approved in June 1941 (although the degree

${ }^{3}$ I. H. Chayes (personal communication, 2004).

${ }^{4}$ For examples of Chayes's discussion of others' work in published comments see: Felix Chayes, Recent studies of Haliburton-Bancroft alkaline rocks: A discussion. Journal of Geology, 1945, 53: 405-508; In defense of the second decimal, American Mineralogist, 1953, 38:784-793; Geological contours and trend surfaces, Journal of Petrology, 1963, 4:307-312; and Reliability of point counting results, American Journal of Science, 1965, 263:719-721.

${ }^{5}$ New York University is a private university, founded in the nineteenth century, not to be confused with CUNY, the modern public system of education in and for New York City.

${ }^{6}$ Irene would become a literary scholar (B.A. and M.A., New York University; Ph.D., Johns Hopkins). She has taught at several American colleges and universities, and published on such topics as the American Southern novel; early James Joyce; the English Romantic poets; and the works of William Blake.

7 I. H. Chayes (personal communication, 2004).

${ }^{8}$ See Felix Chayes, Memorial of Samuel James Shand, American Mineralogist, 1958, 43:317-324.

9 Felix Chayes, Geology of the alkaline and associated intrusive rocks of Bancroft, Ontario [Abstract], Geological Society of America Bulletin, 1939, 50:1904. 
was not formally awarded until commencement in 1942), Chayes thereby became the youngest Columbia student to hold three degrees. ${ }^{10} \mathrm{He}$ was also elected to the Sigma Xi Scientific Research Society. The full results of his work were subsequently published (Chayes 1942b). Chayes inherited Shand's interest in formal methods for the classification and definition of igneous rocks. This was destined to play a large part in his work during the later years of his career and is discussed in more detail below.

While at NYU, Chayes had read an autobiographical, Pulitzer Prize-winning, account of the life of the journalist, historian, and novellist, Henry Adams (18381918) and the growth of America as a world power during Adams's lifetime. ${ }^{11}$ Shortly after Chayes began his graduate studies at Columbia, he made a 'pilgrimage' to Washington, DC, to see Adams's home, and combined this with going to see the Geophysical Laboratory of the Carnegie Institution, then located a few miles away on Upton Street, N.W. Although the laboratory was closed during August, in the course of his visit, Chayes met Ernest Stanley Shepherd (18791949), a physical chemist at the Laboratory, "who at the time was living in the building and following a near-monastic schedule of working in his laboratory, tending garden patches on the grounds, and in the evening, weaving." ${ }_{12}$ It may have been this visit that determined that he would, one day, work at the Laboratory. Although Chayes did not take Shepherd as his rôle model when he at last achieved his ambition, he may originally have seen "in his host's eccentric routine and his freedom to persue it, the promise of a realizable ideal life in science." 13

However, his first, more mundane job was to be hired as a chemist with the Gillis (later, Gillis \& Pawel) Metal Company in Webster, North Carolina for the Summer of 1941. The job ended when Gillis left (possibly in search of financing) ${ }^{14}$ and Chayes returned to New York. In November that year, he took up the post of business-analyst (mineral-economist) with a Washington-based, U.S. government agency, the Office of Production Management, which had been established in January 1941 to direct wartime production and the procurement of materials. ${ }^{15}$ $\mathrm{He}$ and Irene were married in Washington, DC, less than a week after Pearl Harbour, on 13 December, 1941.

In the spring of 1942, Felix was hired as a chemist and petrographer in the Petrographic Unit of the Metallurgical Division, Eastern Experiment Station, U.S. Bureau of Mines at College Park, Maryland. Shortly after this, he was drafted and spent some months at an army camp in Alabama. However, in the interest of the war effort, he was given military leave and recalled to the Bureau in May or June 1942. Because Irene had a job in New York, until then they had been living apart, but they were now able to be reunited. ${ }^{16}$

One of the primary wartime concerns of the Bureau of Mines was the beneficiation of industrial materials and the use of quantitative methods for qualityassurance of the products prepared by the Mineral Dressing Unit at the Eastern Experiment Station. With increasing demand, the analytical requirements far outstripped their capacity for routine chemical analysis and it was therefore necessary to turn to fragment-counting as a control method. Chayes was assigned the task

\footnotetext{
10 N. C. Tenney (personal communication, 2004).

11 Henry Adams, The Education of Henry Adams: An autobiography (Boston: Houghton Mifflin, 1918; reprinted, ed. Ira Nadel, Oxford: Oxford University Press, 1999); the author's house, now an hotel, is in Lafayette Square, opposite the White House.

12 I. H. Chayes (personal communication, 2004).

13 I. H. Chayes (personal communication, 2004).

${ }^{14}$ I. H. Chayes (personal communication, 2004).

15 It was a precursor to the better-known War Production Board, set up in 1942.

16 I. H. Chayes (personal communication, 2004).
} 


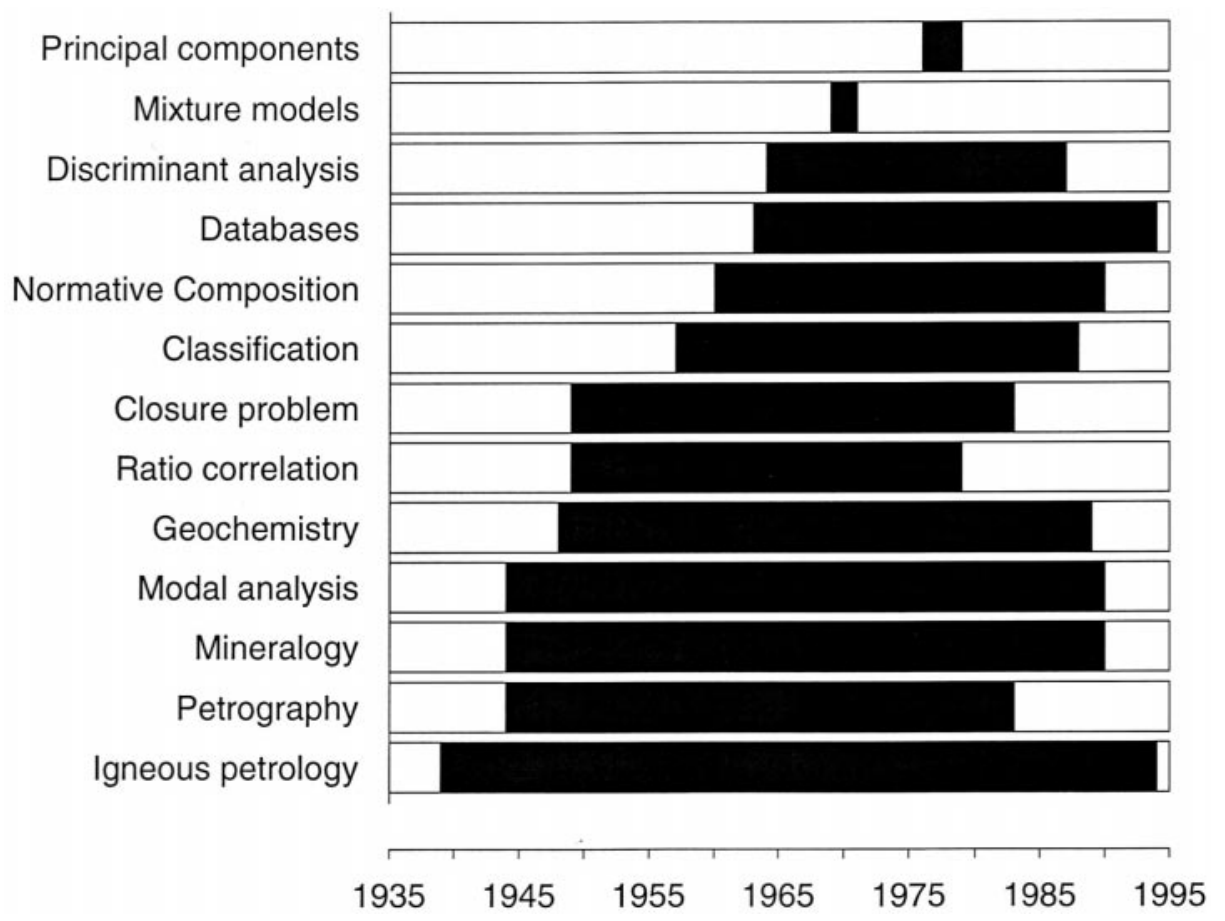

Figure 2. Time-spans of Chayes's 220 publications, classified by subject.

of evaluating the statistical basis of the methods used. This quantitative approach was to become one of the defining characteristics of his career.

In 1946, he began work as mineralogist and petrographer to the Metallurgy Department of the Manhattan Project, now approaching its end, at the Massachusetts Institute of Technology (MIT). While there, Chayes was requested by the geophysicist Leason Heberling Adams (1887-1969), Director (1938-1952) of the Geophysical Laboratory, to prepare a paper on the application of statistical methods to petrological data. This may well have been influential in his being appointed, in May 1947, as a petrographer at the Geophysical Laboratory, thus at last fulfilling his ambition to work there. ${ }^{17}$

Following his initial two-year appointment in 1947, Chayes remained at the Geophysical Laboratory, becoming 'staff petrologist', 1951; 'systematic petrologist', 1986; and 'petrologist emeritus' on his retirement in 1987. In the Yearbooks (Annual Reports of the Director) of the Geophysical Laboratory, parts of Chayes's research program were referred to both as 'statistical petrography' (Chayes, 1965b, 1967, 1971b) and 'statistical petrology' (Chayes, 1975). Figure 2 summarises the time-span occupied by his research publications classified by topic.

Chayes was a member of the Mineralogical Society of America (1943-1993), he was nominated as a fellow in 1943 and elected in 1947 and served as its VicePresident and President (1967); the Geological Society of America (1947-1993); the American Geophysical Union, where he was Secretary of its Vulcanology section (1953-1956); the Geological Society of Washington (1942-1986+,

\footnotetext{
${ }^{17}$ For background on the Geophysical Laboratory, see Carl-Henry Geschwind, Becoming Interested in Experiments: American Igneous Petrologists and the Geophysical Laboratory, 1905-1965, Earth Sciences History, 1995, 14:47-61.
} 
1993?); and a Charter Member (1968-1993) of the International Association for Mathematical Geology (IAMG). ${ }^{18}$

\section{EARLY BEGINNINGS}

As a result of his contact with the Canadian structural geologist Harold Williams Fairbairn (1906-1994), Associate Professor of petrology at MIT, Chayes (1946a, 1949c, 1949d, 1949e) published on the statistical analysis of two- and three-dimensional petrofabric orientation data, ${ }^{19}$ but the main thrust of Chayes's early quantitative work arose from his experiences in the Mineral Dressing Unit of the U.S. Bureau of Mines. While there, he worked on the statistics of uncertainty in fragment-counting related to the process-control of the benification of industrial minerals (Chayes 1944a, 1944b, 1946b), for which a homogeneous endproduct of guaranteed composition would be required. In a second study (Chayes $1946 \mathrm{c})$, he was required to determine the variability of quantitative estimates of the mineral composition (quartz, feldspar, mica, and epidote) of slices of diamonddrill core taken from the coarse-grained Woodstock granite from Granite, Baltimore County, Maryland, quarried since the late nineteenth century for building stone. Small slices of this granite were intended to be used by the Eastern Experiment Station as a reference material for some (unspecified) physical testing procedure. Determinations of quantitative mineral composition were currently being made by direct measurement of the relative total lengths of the mineral grains as measured in a series of traverses across a polished surface or (as in this case) a thin-section of the rock. This approach essentially followed that of Rosiwal (1898), although the task had been subsequently eased by mechanical improvements to traversing microscope stages. Chayes, who had used this technique to a minor extent during his post-graduate sudies, ${ }^{20}$ proved that the point-counting method suggested by Wentworth (1923), in which traverses are regularly-spaced (e.g., $1 \mathrm{~mm}$ apart), was superior to the older Rosiwal procedure in which the maximum grain-diameter set an arbitrary lower limit to the traverse spacing. It is probable that Chayes was first introduced to the Wentworth method by Shand. ${ }^{21}$

18 In his entry in American Men of Science, $9^{\text {th }}$ ed., ed. James M. Catell (Lancaster, PA: The Science Press, 1955), 1:319, and subsequent entries, Chayes includes 'Statistical Association' among his society memberships. However, the American Statistical Association membership records from 1945 to the present do not list Chayes as ever having been a member (Michael Roberts, personal communication, 2004) and I have been unable to obtain information regarding his possible membership from the plausible alternative of the Statistical Society of Washington.

19 Petrofabrics, which has also been known as 'structural petrology', is the study of the fabric of mineral orientation (generally quartz, biotite, or muscovite) in a rock, with a view to understanding its deformation history; for more background, see Richard J. Howarth, Measurement, portrayal and analysis of orientation data and the origins of early modern structural geology (1670-1967), Proceedings of the Geologists' Association, 1999, 110:273-309.

${ }^{20}$ Felix Chayes, Alkaline and carbonate intrusives near Bancroft, Ontario, Geological Society of America Bulletin, 1942, 53:449-511; modes of six syenites and quartz syenites on 478.

21 Shand developed a micrometer for this type of work: Samuel J. Shand, A recording micrometer for rock analysis, Journal of Geology, 1916, 24:394-403; Chayes, Bancroft, 1942, 479, 481 mentions an 'integrating micrometer'. Chayes was not, of course, the only person to be undertaking modal analysis of granitic rocks at this time (see, for example, Arthur F. Buddington, Origin of granitic rocks of the northwest Adirondacks, in Origin of granite, ed. James Gilluly (Conference at Meeting of The Geological Society of America held in Ottawa, Canada, December 30, 1947), Geological Society of America Memoir, 1948, 28:21-43), but Chayes's use of the faster point-count method enabled him to make very much larger numbers of modal analyses. 


\section{NEW ENGLAND GRANITES}

\section{Quantitative Modal Analysis}

A 'bitter controversy' 22 over the origin of granites, which had rumbled on since the nineteenth century, reached new heights in the late 1940s-championed by Norman Levi Bowen (1887-1956) of the Geophysical Laboratory and Herbert Harold Read (1889-1970) of Imperial College, London, England: Bowen advocated evolution by fractional-crystallization and differentiation of magma, whereas Read acknowledged that although some granites might be of igneous origin, there was no reason why others might not have been produced by 'granitization', i.e., the transformation of metamorphic rocks into granite without passing through a magmatic stage. Read, whose primary concern was with the 'space problem' of magmatic injection, regarded it as a problem soluble on the basis of evidence from the field rather than the laboratory. On 30 December 1947, the Geological Society of America held a symposium on the origin of granite in Ottawa, Canada, as part of the centenary celebrations for the Geological Survey of Canada. Read and Bowen were the principal speakers. Shand and, it would seem, Chayes, among others, attended..$^{23}$

The motivation for Chayes's work on the quantitative petrography of granites becomes apparent from two subsequent papers: ${ }^{24}$ On joining the Geophysical Laboratory, he had begun a systematic investigation of the finer-grained calcalkaline granites of New England, with a view to supplementing the usual qualitative descriptions by quantitative data on their mineral composition. Rather than risk possible time-consuming complications which might arise from attempting this by fragment analysis, he undertook 'modal analysis', i.e., the quantitative determination of the relative volumetric abundance of the rock-forming minerals (in this case quartz, orthoclase, plagioclase, biotite, muscovite, and total opaque and non-opaque accessory minerals) as seen in thin-section (Figure 3). Chayes estimated their relative proportions by 'point-counting' the numbers of occurrences of each mineral type encountered at regular grid intersections in a set of finelyspaced systematic traverses across a thin-section "not less than $3 / 4$ inch or more than 1 inch square" (ca. 190 by $250 \mathrm{~mm}$ ), using a mechanical stage and counters which he developed himself (Chayes 1949b,c). His attitude to the number of points counted (typically ca. 1,400$)^{25}$ was that it should be what we would today

${ }^{22}$ Felix Chayes, Composition of some New England granites, Transactions of the New York Academy of Sciences, 1950, 12:144-151, on 144.

${ }^{23}$ Implied in Felix Chayes, A petrographic criterion for the possible replacement origin of rocks, American Journal of Science, 1948, 246:413-425, on 413; James Gilluly, ed., Origin of granite Conference, 1948; the other speakers were Arthur F. Buddington (1890-1980), Frank F. Grout (1880-1958), and George E. Goodspeed (1887-1974); Gilluly lists twenty-six discussants, including Shand, on vii.

${ }^{24}$ Chayes, New England granites, 1950, 144-151; Felix Chayes, The finer-grained calcalkaline granites of New England, Journal of Geology, 1952, 60:207-254, on 207-208.

25 Chayes, Calcalkaline granites, 1952, 237. It is difficult to tell how many points Chayes routinely counted, since this is not explicitly stated in his early papers. Remarks in his monograph, Petrographic Modal Analysis (New York: Wiley, 1956) on 42 and 65, suggest it was ca. 1500 points per slide; Felix Chayes, A simple point counter for thin section analysis, American Mineralogist, 1949, $34: 1-11$, on $3,6,7$, gives a mean of 1391 (ideally, 1400) points spaced at $0.3 \mathrm{~mm}$ in one direction and $1 \mathrm{~mm}$ in the other to cover an area of this size when point-counting granite thin-sections. Felix Chayes, On a distinction between late-magmatic and post-magmatic replacement reactions, American Journal of Science, 1950, 248:52-66, on 31 gives a mean of 1421 (range 1281-1521) points counted on twenty-one thin-sections of the Barre granite, Vermont. The point-count method was originally introduced by A. A. Glagolev, in: On the geometrical methods of quantitative mineralogical analysis of rocks [Russian with English summary], Trudy Instituta Prikladnoi Mineralogii I 


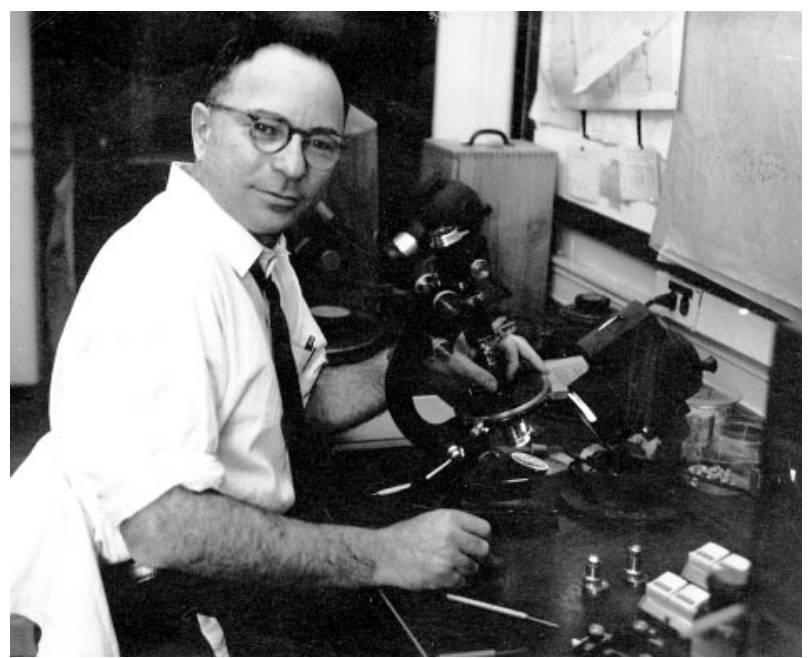

Figure 3. Felix Chayes at the petrological microscope (?1951). Note counters used for recording modal analysis counts in lower right. Reproduced with permission of the Geophysical Laboratory, Carnegie Institution of Washington.

call 'fit for purpose'. ${ }^{26}$ In order to aid this work, Chayes (1952b) also developed a method which used chemical staining to achieve better distinction of potassium feldspar from untwinned acid plagioclase when viewed in thin-section. This improved on the method of Keith (1939) and rapidly became established as the standard technique.

Chayes's investigation of the reproducibility of the point-count technique for modal analysis was initially based on his own duplicate analyses of a total of forty-seven thin-sections from three New England granites: Milford, New Hampshire; Westerly, Rhode Island; and Barre, Vermont. ${ }^{27}$ He subsequently examined a set of triplicate thin-sections prepared from eleven hand-specimens from quarries in the Westerly granite and five hand-specimens from the Bradford granite, also located in Rhode Island (Chayes 1950a). Because of non-standard aspects of the analysis of variance required to analyse the data, Chayes sought the statistical advice of Joseph M. Cameron (d. 2000) and William Young ("Jack") Youden (1900-1971) of the Statistical Engineering Laboratory of the National Bureau of Standards (NBS), Washington, DC, regarding the most appropriate analysis of variance design for the data analysis. Statistically-significant differences between the compositions of the thin-sections could not be detected, thus suggesting a considerable degree of homogeneity in the composition of the rock. (Cameron would continue to provide him with advice and, in the 1960s, computer facilities)..$^{28}$

Petrografii, Moskva [Transactions of the Institute of Economic Mineralogy and Petrography, Moscow], 1933, 59:1-47; and A. A. Glagolev, Quantitative analysis with the microscope by the point method. Engineering and Mining Journal, 1934, 135:399-400.

${ }^{26}$ Chayes wrote: "For practical purposes we need require only that the precision error of a single analysis be small in relation to the expected differences between rocks." (Chayes, Point counter, 1949, 10).

27 Chayes, Point counter, 1949, 4.

28 Felix Chayes, 1950, Composition of the granites of Westerly and Bradford, Rhode Island, American Journal of Science, 1950, 248:378-407 on 404; Felix Chayes, On correlation between variables of constant sum, Journal of Geophysical Research, 1960, 65:4185-4193, cf. 4193. It is not clear why 
In May 1950, Chayes enlisted the help of Fairbairn and four petrographers at MIT in a collaborative trial of the point-counting method to determine the magnitude of between-operator variation. Their results (Chayes and Fairbairn 1951) again confirmed the practicality of Chayes's technique, but suggested that between-operator variation could be significant. This reinforced Chayes's view ${ }^{29}$ that an investigation of modal variation among- and within-granites in a region was best carried out by undertaking all the modal analyses oneself, rather than relying on data from the literature (where such existed).

When Chayes began his research program on these fine-grained granites, he envisaged a systematic progression of small investigatory studies: first testing (through the examination of replicates) the homogeneity of each granite at the scale of thin-sections cut from a single hand-specimen, then progressing to studying the variation at the scale of "a small working face in a quarry, then to an entire quarry, then to a cluster of quarries, and, finally, to an entire granite mass." ${ }^{30}$ However, in an initial pilot project, Chayes visited a number of quarries, taking a single hand-specimen from each. To his surprise he found, on examining the suite of thin-sections, that the variation "from a given quarrying district was so small as to indicate that more detailed sampling was likely to prove unprofitable so long as the work was confined to granites of finer grain." 31 By the end of two field-seasons, Chayes had obtained samples from all the well-known quarries in New England, which extended over an area of some $20,000 \mathrm{mi}^{2}\left(51,800 \mathrm{~km}^{2}\right)$. His collective results suggested that, for the same granite body, the variation between specimens taken a mile $(1.6 \mathrm{~km})$ apart was virtually the same as for those taken within a few feet $(0.3 \mathrm{~m})$ of each other.

Furthermore, he found that when the data for the modal compositions of his 145 thin-sections was expressed in terms of the re-percentaged constituents: total feldspar (F), quartz (Q), and mafic minerals (M; biotite, muscovite plus accessory minerals) they plotted essentially as a single dense cloud in the Q-F-M ternary diagram. ${ }^{32}$ When he contoured the spatial density of these points, ${ }^{33}$ he found that they occupied only four percent of the diagram and had a maximum spatial density of nine percent per unit area; he remarked "concentrations of this order are unknown in petrofabrics." 34 As Chayes pointed out, what was still more remarkable was that these data points

are in no sense either averages or estimates of bulk composition. Each point is a plot of the result of a single analysis of a single thin section less than 1 inch in area. So far as it represents any real quantity of rock at all, the relevant volume is not that of a stock or a quarry or even a hand specimen; it is, at most, the volume of a single thin section, perhaps 1/1000 of a cubic inch. This absurdly small sample is taken in the worst possible fashion, with no sifting, rolling,

Chayes needed to use NBS computing facilities as it would seem that by 1961 he had use of a computer at the Geophysical Laboratory (Felix Chayes, Notes on the prehistory and early history of digitised data bases and related information systems in igneous petrology, Episodes, 1990, 13: 18-21, cf. 18-19).

${ }^{29}$ Chayes, New England granites, 1950, 146.

30 Chayes, Calcalkaline granites, 1952, 237-238.

31 Chayes, Calcalkaline granites, 1952, 238.

32 A specialised type of graph showing composition in terms of relative proportions of three endmembers; see Richard J. Howarth, Sources for a history of the ternary diagram, British Journal for the History of Science, 1996, 29:337-356.

${ }^{33}$ Chayes was already used to contouring petrofabric diagrams (he discusses this in Felix Chayes, Application of the coefficient of correlation to fabric diagrams, Transactions of the American Geophysical Union, 1946, 27:400-405); he now used a hexagon of 0.12 percent area passed over the mesh of the ternary diagram, rather than the 1 percent area circular counter used in petrofabric analysis.

${ }^{34}$ Chayes, New England granites, 1950, 147. 
or homogenization of any sort. What is more, no two thin sections are from the same hand specimen, most of the hand specimens are from different quarries, and the quarries are widely scattered over New England. We are here in the presence of petrology's major mysteries, a mystery no serious hypothesis can afford to scoff at or fail to rationalise. ${ }^{35}$

He went on to argue that, although compositional differences between individual granites did exist, "as neither the sample size nor the total range of variation is large, we must conclude that the internal variability is very small indeed. It is, I believe, far smaller than the most sanguine magmatist had anticipated." 36

Chayes suggested that were the granites to have been derived by a granitizing agent penetrating a mass of highly siliceous sedimentary or metamorphic rocks, one might expect to find high quartz contents (say, $>75$ percent) in the granite. Alternatively, one might reasonably expect that a feldspathization process might occasionally "overshoot a little" to generate small patches of syenite, e.g., detectable at a scale of inches $(\mathrm{cm})$. Yet, in his collection of thin sections, the quartz content was restricted to between 20 and 40 percent. He commented

what kind of feldspathization process is it that works perfectly wherever it finds more than 40 percent of quartz and fails completely when it reduces the quartz content to 20 percent? Such a process operating on a very coarse scale and speaking only in terms of average or bulk compositions is hard enough to credit. What are we to say when it works at a scale of square inches of area and on volumes of the order of a thousandth of a cubic inch? ${ }^{37}$

Consideration of the modal percentages of quartz $(\mathrm{Q})$, orthoclase (Or), and plagioclase $(\mathrm{Pl})$ in the granites touched on another aspect of the problem. Since 1912, when Bowen joined the Geophysical Laboratory, he and his colleagues had been carrying out experimental studies of the crystallization behaviour of mineral systems. In 1935, Bowen and J. Frank Schairer (1904-1970) had begun work to establish the crystallization-temperature surface for mineral mixtures in the ternary feldspathoid-silica system nepheline-kaliophilite-silica $\left(\mathrm{NaAlSiO}_{4}-\mathrm{KAlSiO}_{4^{-}}\right.$ $\mathrm{SiO}_{2}$ ) and its silicate-rich feldspar-silica subsystem, albite-orthoclase-silica $\left(\mathrm{NaAlSi}_{3} \mathrm{O}_{8}-\mathrm{KAlSi}_{3} \mathrm{O}_{8}-\mathrm{SiO}_{2}\right)$. In 1937, Bowen identified the presence of a lowtemperature 'thermal trough' in this surface. He postulated that the fractional crystallization of a magma of basaltic composition should result in a liquid residue whose composition approaches and finally enters the thermal valley. Unless heat is added, the liquid cannot escape from the valley, and the composition of the crystallizing mass will remain within it. Furthermore, he demonstrated that the CIPW normative percentage ${ }^{38}$ of albite, orthoclase, and silica calculated from the chemical analyses of a collection of forty volcanic rocks (rhyolites, trachytes and phonolites) from the East African Rift plotted in, or very close to, this thermal trough. ${ }^{39} \mathrm{He}$ argued that this showed that the volcanic rocks must have originated from the residual liquids produced by extreme fractional crystallization of a ba-

35 Chayes, New England granites, 1950, 147.

36 Chayes, New England granites, 1950, 147.

${ }^{37}$ Chayes, New England granites, 1950, 148.

38 The normative mineral composition of a rock consists of the weight percentages of a suite of minerals of ideal composition, whose proportions are calculated by a series of fixed rules (e.g., the CIPW norm or Niggli norm) from the major-element oxide chemical composition of the rock: C. Whitman Cross, Joseph P. Iddings, Louis V. Pirsson, and Henry S. Washington, A quantitative chemico-mineralogical classification and nomenclature of igneous rocks, Journal of Geology, 1902, 10:555-693; Paul Niggli, Lehrbuch der Mineralogie, 2 vols. (Berlin: Bornträger, 1920).

${ }^{39}$ Norman L. Bowen, Recent high-temperature research on silicates and its significance in igneous geology, American Journal of Science, 1937, 33:1-21. 


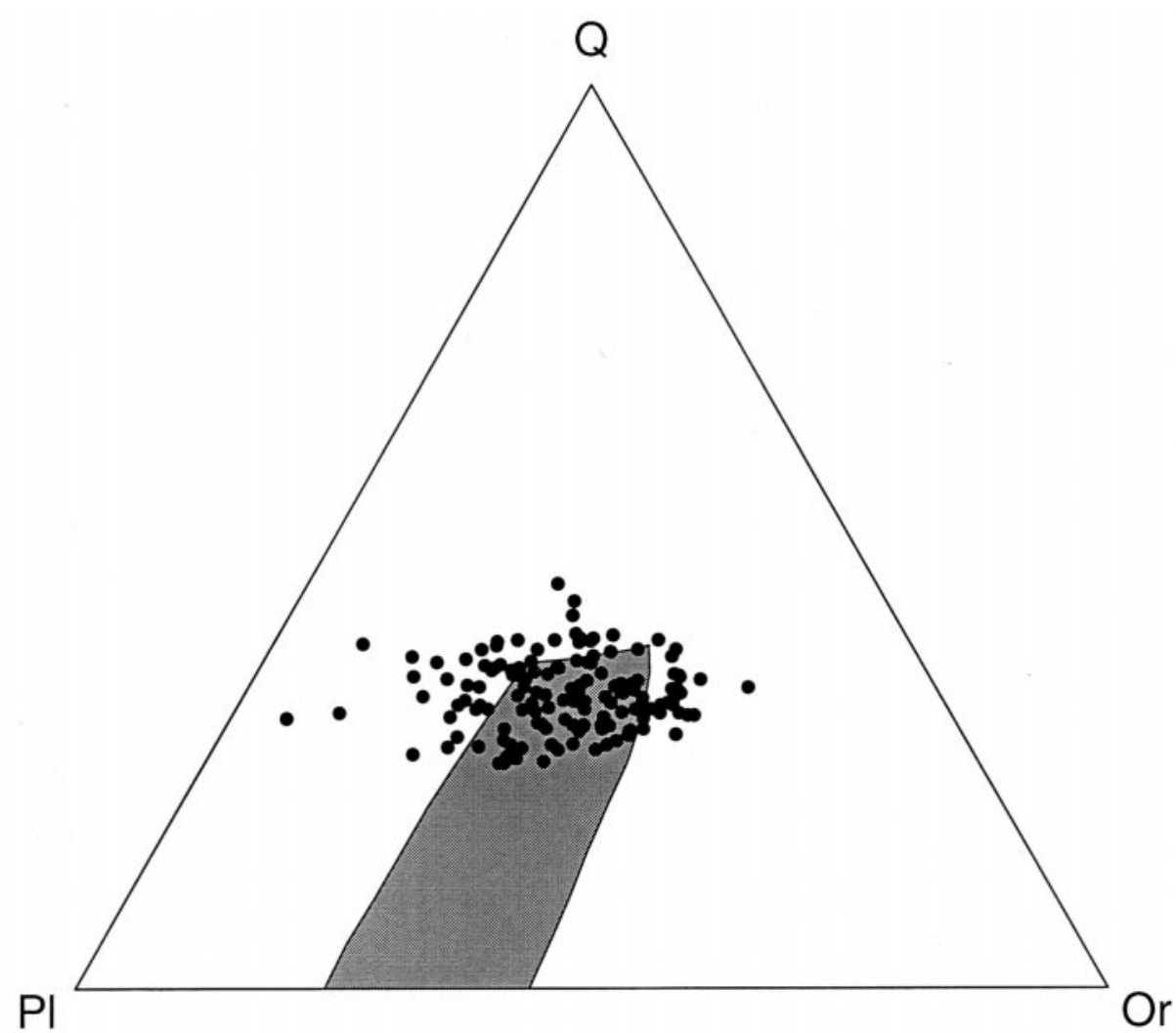

Figure 4. Modal proportions of quartz (Q), plagioclase (Pl) and orthoclase $(\mathrm{Or})$ in 145 specimens of the finer-grained calcalkaline granites of New England in relation to location of Bowen's thermal valley (shaded). Chayes realised that the superposition was something of a compromise, as Bowen's experimental data was for $\mathrm{SiO}_{2}-\mathrm{Or}$-Ab, but plagioclase in granites is mainly Ab. Data from Felix Chayes, The finer-grained calcalkaline granites of New England, Journal of Geology, 1952, 60:207254 and Norman L. Bowen, Recent high-temperature research on silicates and its significance in igneous geology, American Journal of Science, ser. 5, 1937, 33:1-21. In Chayes (1952a), plots of this type are given for the individual granite bodies (one is partly visible on the wall in Figure 3), but there is no composite view of the data.

saltic magma. ${ }^{40}$ Note that, compositionally, these rocks are the equivalent of the plutonic granites, syenites, and nepheline-syenites.

Returning to the New England study, Chayes found that when the modal percentages for his granites were plotted on a Q-Or-Pl diagram (Figure 4), all the results for the Westerly, Bradford, and Milford granites fell within the silica-rich end of the thermal valley identified by Bowen; the points for eight of the rest were largely within the valley (with a few points lying outside, but still adjoining the same side of the valley); and in only one case (Westwood, Massachusetts) was the cluster of points entirely outside the valley. Chayes concluded that this evidence was consistent with the magmatic hypothesis "by which I mean simply the notion that each of these granite masses has formed by crystallization of a liquid of approximately the same composition as the finished product" and that

40 Bowen believed that this was so important that he called the nepheline-kaliophilite-silica system "petrogeny's 'residua' system"; petrogeny being a synonym of petrogenesis, the science of the formation of rocks; and residua, the plural of residuum — 'that which remains'. 
the compositional variability shown was very much smaller than one might expect to occur under the non-magmatic origin hypothesis. Despite a need to ensure the adequacy of the sampling procedure, he concluded

I believe that sufficient evidence has now been offered in support of the assertion that the availability of large numbers of reliable quantitative modal analyses would immediately and powerfully affect discussions of the origin of rocks. A systematic quantitative petrography would be well worth having. ${ }^{41}$

Chayes (1952a) gives a more detailed account of these results.

In 1949, he undertook a similar sampling programme of the Precambrian granites of the Llano-Burnet area of central Texas, which he extended to the southeastern states the following year. ${ }^{42}$

E. H. T. Whitten (pers. comm., 2004) suggests that the unusual homogeneity of the New England granites influenced all Chayes's future thinking and work, particularly leading to his compilation of geochemical databases in later years.

An interesting by-product of his work in New England was that Fairbairn (who with his MIT colleague, the geochemist Louis Herman Ahrens (1918-1990), was embarking on a program to examine the potential of spectrographic analysis as a replacement for the traditional wet-chemical silicate analysis) learnt of Chayes's intention to use the Westerly granite for early trials in his evaluation of the point-count modal analysis technique (Chayes 1950a). Accordingly, in June 1947, at Fairbairn's request, Chayes purchased a block of granite, $6 \mathrm{ft}(1.8 \mathrm{~m})$ long by 6 in $\times 6$ in $(152 \mathrm{~mm} \times 152 \mathrm{~mm})$ in cross-section, from the Smith Granite Company, Westerly, Rhode Island. Prior to crushing, eight evenly-spaced 4 in $(100 \mathrm{~mm})$ thick blocks were cut out of the strip; the ends of these yielded 16 thin-sections, which Chayes used for modal analysis. He then crushed the remainder of the material to produce $96 \mathrm{lb}(43 \mathrm{~kg})$ of homogenised -80-mesh granite powder. This was sub-divided into 562 jars, each labelled ' $\mathrm{G}-1$ ' and containing about $76 \mathrm{~g}$ of powder. As well as providing Fairbairn and Ahrens with a reference material, it also became the first U.S. Geological Survey geochemical standard. Its definitive mineral composition (Chayes, 1951) and the results of the collaborative geochemical trial which attempted to estimate preferred values for its elemental composition are reported in Fairbairn (1951). ${ }^{43}$

\section{Statistical Insight}

Chayes realised that statistical methods might be able to bring greater exactitude to the solution of these petrographic problems. He wrote:

The substance of the granitization controversy is of the utmost importance to petrology, but its form is also typical of a great many quarrels of less significance, and perhaps of petrographic reasoning as a whole. Generally we seem content to reach hypotheses that can not be shown to be impossible, leaving to the dictates of "common sense," previous experience, or authority the decision as to which of these not impossible hypotheses is to be preferred in a particular situation. . . . We urgently require a method of analysis that will help us weed out misleading or unlikely hypotheses so that we may devote our attention to modification, extension, and elaboration of the more fruitful traditional concepts. At present we have no such method, but I

${ }^{41}$ Chayes, New England granites, 1950, 150-151.

42 Chayes, Calcalkaline granites, 1952, 238.

${ }^{43}$ The same report describes the collection and preparation (by others) of the diabase reference material 'W-1' and Chayes's modal analyis of this rock. When supplies of G-1 were about to run out, Chayes collected a second sample from the Sullivan quarry, approximately $3 \mathrm{mi}(5 \mathrm{~km})$ east of the site where G-1 was collected, and again determined the modal composition of this new reference material (Felix Chayes, Modal composition of USGS reference sample G-2, Geochimica et Cosmochimica Acta, 1967, 31:463-464). 
believe we might obtain one by a careful, systematic adoption and adaption of the simpler, basic procedures of small sample statistics, as now practiced chiefly by biologists. ${ }^{44}$

Chayes (1948) suggested that if a rock is formed by a reaction in which one group of minerals replaces another, then an inverse correlation between the quantity (by weight or volume) of original mineral and that of the reaction-product should be expected, and that this should be detectable either by modal analysis, or from geochemistry. However, "if any hypothesis calls for a significant negative correlation not exhibited by the data, we are justified ... in asserting that the data do not support the hypothesis" [italics as in original]. ${ }^{45}$ Chayes re-examined data on normative ${ }^{46}$ quartz $(\mathrm{Q})$ and total orthoclase $(\mathrm{Or})$ plus albite $(\mathrm{Ab})$ in forty specimens of Scandinavian rapakivi granites, which had been used by the Swedish petrologist Helge G. Backlund (1878-1958) to support his thesis that the (Mesoproterozoic) Jotnian sandstones could have been transformed into rapakivi granite by a 'granitization' process (the 'alkali-emanation hypothesis'), which introduced $\mathrm{Na}, \mathrm{K}$, and $\mathrm{Ca}$ aluminates without volume change. Chayes showed that if the data for each of these five granite bodies were considered separately (rather than taken together, as Backlund had done), then only the two Swedish cases exhibited negative correlation between $\mathrm{Q}$ and $(\mathrm{Or}+\mathrm{Ab})$; there was no correlation in the data for any of the three Finnish granites.

In this paper, Chayes also brought geologists' attention, for the first time, to the statistical problems posed by "tables that form so much of the petrographer's data (tables of full chemical analyses, or of modes or norms)" in which

the sum of the variates is itself a variable ... [which] is actually, or practically, constant. The effect of this condition is to generate negative correlation. Although the statistics computed from such tables offer a more adequate description than can usually be obtained graphically or by inspection, their utility as probability statements is limited unless proper account is taken of the tendency'. ${ }^{47}$

He introduced the term, a 'closed' table for one with this constant-sum property; distinguishing it from an 'open' table, in which the sum of the variates is itself a variable: "Statistics ordinarily deals with open tables; closed tables are the mainstay of chemical petrography." 48 Chayes implied that this induced negativecorrelation effect served to lower the apparent significance of the result for the two Swedish granites. He concluded that overall there was no evidence that a consistent mechanism operated and that Backlund's hypothesis was consequently unproven.

As seen above, by 1950, Chayes had come out as a convinced magmatist: "I am guilty of the assumption that there is a (granite) magma and that it consists of a mixture of crystals and liquid, for it is in this way that I have been able to make the most sense of the observations" as distinct from those who "think in terms of alkali-emanations, 'clouds of ions,' or wholesale metasomatism." $49 \mathrm{He}$ was convinced that classical petrography had proved unable to provide the kind

\footnotetext{
44 Chayes, Petrographic criterion, 1948, 413-414; he cites the textbooks by George W. Snedecor, Statistical methods, $4^{\text {th }}$ ed. (Ames, Iowa: Iowa State College Press, 1946) and George U. Yule and Maurice Kendall, An Introduction to the Theory of Statistics, 13 ${ }^{\text {th }}$ ed. (London: Griffin, 1946).

45 Chayes, Petrographic criterion, 1948, 417.

46 Different sets of rules for calculating norms were proposed at different times by Cross, Iddings, Pirsson, Washington, Niggli, Tom F. W. Barth (1899-1971) and others; see Davis A. Young, Mind Over Magma. The story of igneous petrology (Princeton: Princeton University Press, 2003), for further discussion. During his thesis work, Chayes calculated norms for his chemical analyses of rocks.

47 Chayes, Petrographic criterion, 1948, 415.

${ }^{48}$ Chayes, Petrographic criterion, 1948, 416.

49 Chayes, Replacement reactions, 1950, 23.
} 
of evidence required to resolve the granite controversy, and that the answer lay in the application of systematic quantitative petrography: The fact that all granite bodies tend to be very similar in average or bulk composition was not in itself particularly definitive in distinguishing between hypotheses.

With regard to internal variations in the composition of each mass, however, the assumption of an initially homogeneous parent material leads to inferences diametrically opposed to those drawn from other hypotheses. Reliable quantitative information about the internal variability of granite masses might thus go a long way toward settling the problem. For the magmatic hypotheses do in general contain the assumption of a homogeneous parent, while this assumption is conspicuously lacking in the nonmagmatic hypotheses, and its absence is usually intentional [my italicization]. ${ }^{50}$

He now revisited the evidence for replacement, this time using his own modal data from the Barre granite, and postulated that

the distribution of the pseudomorphous replacements in a rock mass will depend on the distribution of magmatic residues through the mass at the time of the reaction. If the reaction occurs before these residues have been expelled from some parts of the [magma] chamber and concentrated in others, the amount of replacement mineral $(R)$ formed will be roughly proportional to the amount of original mineral available for reaction $(O)$. There will be positive correlation between $O$ and $R$ and it is not likely that correlation between $O$ and $(O-R)$, the amount of original mineral surviving the reaction will be significantly negative... . If the reaction does not occur until there has been extensive separation of liquid residue from crystallized material, however, the amount of $R$ will be essentially independent of $O$, and the quantities $R$ and $(O-R)$ will be negatively correlated. ${ }^{51}$

Chayes showed that in the Barre granite, in which 82 to 96 percent of the muscovite occurs as a pseudomorphous replacement of plagioclase, there was a strong positive Pearson correlation coefficient $(+0.58 ; n=21)$ between $R$, the amount of replacement muscovite in plagioclase, and $O$, the amount of original plagioclase, which he estimated as total (plagioclase + carbonate $+R$ ); and a weaker positive correlation $(+0.21)$ existed between $R$ and $(O-R)$. He concluded that the results supported the first, late-magmatic reaction, model.

From the statistical point of view, Chayes was fully aware that since the quantity $R$ was also included in the estimate of $O$, this involved 'whole-part correlation', as discussed in the textbooks of Snedecor (1946) and Yule and Kendall (1946); the nub of the problem being that there would inevitably be some degree of positive correlation because of the commonality of $R$ in the two variables. The problem was: how large did the observed correlation coefficient have to be to reflect a real causative relationship? He did not attempt to offer a solution to this conundrum but, like the effects of closure, it was a subject to which he would return in future work.

\section{PETROGRAPHY AND MINERALOGY}

It has been shown how Chayes first developed the point-counting method and demonstrated its efficacy as a tool for quantitative petrography, hopefully bringing greater rigor to the solution of petrological problems. His early work was essentially focused on the properties of fine-grained granites. As time went on, he undertook numerous investigations (e.g., Chayes 1950b, 1953, 1954a, 1954d, 1955a, 1956a) to establish, from a firm statistical foundation, both the precision of the technique and the sample sizes required to give satisfactory results when it was applied to coarse-grained rocks. As a result of his being invited to give a series of lectures on the topic at the California Institute of Technology in

${ }^{50}$ Chayes, New England granites, 1950, 145.

${ }^{51}$ Chayes, Replacement reactions, 1950, 35-36. 
1955, these studies were eventually brought together in a monograph, Petrographic modal analysis (Chayes 1956b) which became the standard reference work on this topic. By the mid-1960s, the growing availability of rapid instrumental majorand trace-element analysis (e.g., by X-ray fluoresence), and the ease of computeraided calculation of normative mineral compositions, were causing a gradual decline in what was seen by many as tedious and time-consuming quantitative petrographic analysis. In 1986, Chayes gave a talk to the Geological Society of Washington on "Whatever became of descriptive petrography?" in which he lamented the lack in current work of petrological descriptions of mineral assemblages, and of modal analyses of the minerals actually analysed, to accompany geochemical analyses. The reaction of the rapporteur was "fussy, fussy, fussy." 52

The majority of Chayes's mineralogical investigations were concerned with methods for the determination of the composition of the plagioclase feldspar series, albite-anorthite $\left(\mathrm{NaAlSi}_{3} \mathrm{O}_{8}-\mathrm{CaAl}_{2} \mathrm{Si}_{2} \mathrm{O}_{8}\right.$ ) from measurements of refractive index (Chayes 1950c, 1952d, 1954c) or using X-ray diffraction (Chayes 1959; Suzuki and Chayes 1961).

Chayes's early investigations of granites in various parts of the United States have already been mentioned. Additional papers touched on more mineralogical aspects (e.g., Chayes 1952c, 1954b, 1955b; Robbins and Chayes 1956). However, by 1960 , the growing availability of geochemical data meant that Chayes and his co-workers at the Geophysical Laboratory were beginning to use the computer for the calculation of CIPW normative mineral compositions. ${ }^{53}$ In 1961, the Spanish petrologist, José L. Brändle, began work with Chayes to assemble a punchedcard database (in 80-column format) of major-element analyses of Cenozoic volcanic rocks (J. Brändle, ${ }^{54}$ pers. comm., 2003). This enabled greater use of geochemistry as an additional tool in the investigation of petrological problems. Major oxide concentrations are expressed as percentages and, with the inclusion of $\mathrm{H}_{2} \mathrm{O}$, a 'good' analysis should total close to 100 percent (Washington, 1919). Chayes's knowledge of statistics made him realise that (as he had already pointed out in the case of modal data) the presence of such 'closed' tables of geochemical data presented considerable problems when it came to the interpretation of geochemical trends, because of induced negative correlations between $\mathrm{SiO}_{2}$ and the other majors as an inevitable consequence of increasing silica content.

\section{GEOCHEMISTRY OF LAVAS}

As noted above, in 1961 Chayes began compiling a database of major-element analyses, obtained from the published literature, of Cenozoic volcanic rocks from localities on oceanic islands and bordering the oceans (Chayes 1962). His related research focused on two principal topics: the reality of the so-called 'Daly

52 Report of meeting of the Geological Society of Washington, 26 March 1986, http:// www.gswweb.org/minutes/GSW1986.htm.

53 Chayes, Prehistory, 1990, cf. 18-19. For Chayes's publications on CIPW norms see: Felix Chayes, Occurrence of normative sodium metasilicate in Washington's tables, Geological Society of America Bulletin, 1960, 71:503-504; Felix Chayes, On pyroxene molecules in the CIPW norm, Geological Magazine, 1963, 100:7-10; Felix Chayes and Hatten S.Yoder, Jr., Some Anomalies in the Norms of Extremely Undersaturated Lavas, Year Book, Carnegie Institution of Washington, 1971, 70:205206.

54 Jose L. Brändle, Linkage between petrology and mathematics, with especial reference to Prof. Felix Chayes. Keynote Lecture, IAMG98 meeting, 5 October 1998, unpublished lecture notes. See also: Jose L. Brändle, Niichi Nishiwaki, and Geza Nagy, Linkage between petrology and mathematics, with special reference to Prof. Felix Chayes, in Antonella Buccianti, Giuseppe Nardi, and Roberto Potenza, eds., Proceedings of the fourth annual conference of the International Association for Mathematical Geology (Ischia: International Association for Mathematical Geology, 1998), 54-64. 


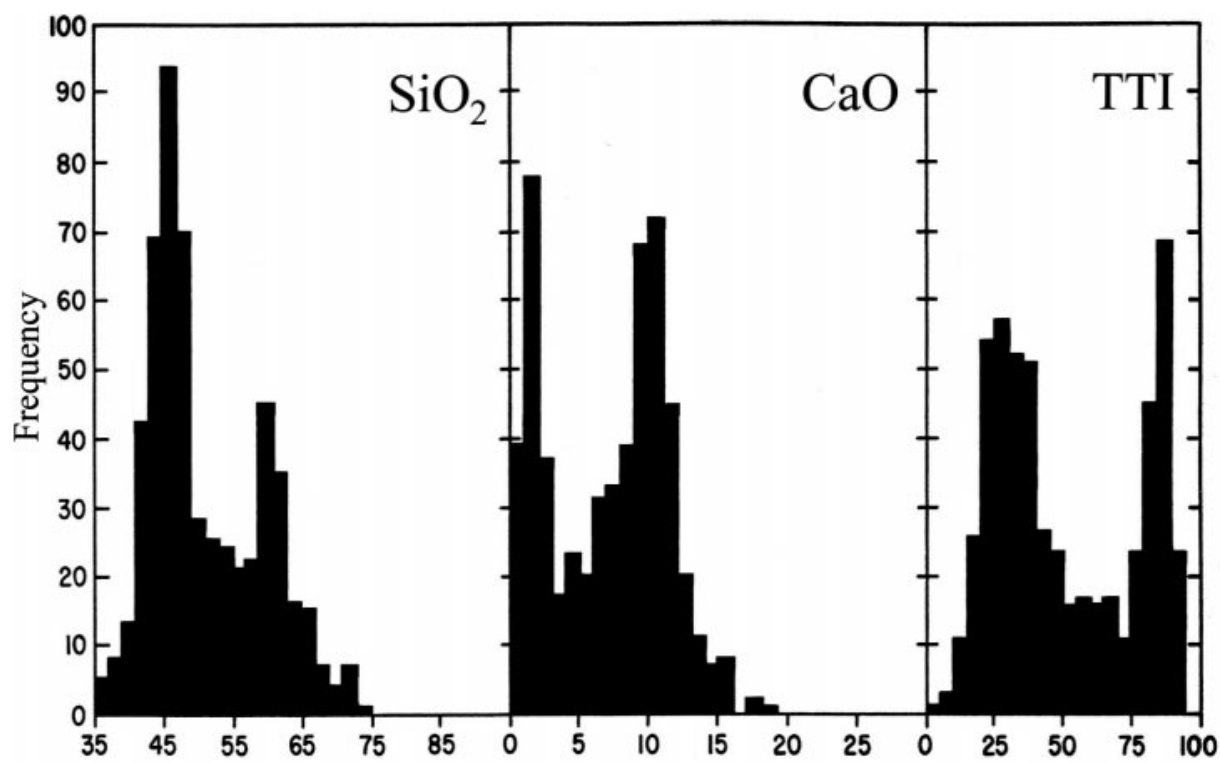

Figure 5. Bimodal frequency distributions for $\mathrm{SiO}_{2}, \mathrm{CaO}$, and the Thornton-Tuttle Index of 551 lavas from islands in the Pacific, Atlantic and Indian Oceans. Redrawn, with permission of the Journal of Geophysical Research, from Figures 1a, 2a, and $3 a$ of Felix Chayes, Relative abundance of intermediate members of the oceanic basalt-trachyte association, Journal of Geophysical Research, 1963, 68:1519-1533.

gap', i.e., the apparent lack of abundance of intermediate members of the oceanic basalt-trachyte association, to which attention had first been drawn by the petrologist Reginald Aldworth Daly (1871-1957) in 1925; ${ }^{55}$ and finding geochemical criteria to distinguish between intra-oceanic and circum-oceanic basalts. Figure 5 shows frequency distributions for $\mathrm{SiO}_{2}, \mathrm{CaO}$, and the so-called Thornton-Tuttle Index (the sum of CIPW-normative nepheline, leucite, Or, Ab, and Q) of lavas from islands in the Pacific (174 analyses), Atlantic (298) and Indian (79) Oceans. A strongly bimodal distribution is apparent in all three histograms and Chayes argued that the original samples must have been sufficiently representative that this reflected a real feature of the lava compositions which could not be explained by crystal fractionation alone. Needless to say, this was an enormously contentious conclusion. It called forth a great deal of criticism about whether such a hypothesis, based on a possibly unrepresentative sample of data drawn from the literature, could possibly be correct. Nevertheless, Chayes persisted in this view, reinforcing his argument as his database gradually amassed, increasing from 340 analyses (Chayes 1963) to over 9,600 (Chayes 1972). He revisited the topic in a series of papers (Chayes 1964a, 1966, 1972e, 1977e) and in Chayes (1977) he showed that the same phenomenon even existed within a suite of 979 specimens from the Canary Islands. Today, it is accepted that the Daly gap is, indeed, real and ubiquitous, even in lava suites from submarine ridges and a variety of mechanisms have been proposed as alternatives to the unsatisfactory explanation of fractional crystallisation (see Bonnefoi, et al. (1995) and references therein).

55 In Reginald A. Daly, Igneous Rocks and their Origin (New York: McGraw-Hill, 1914). Daly first drew attention to the fact that while basalt predominates among volcanic rocks and granite among plutonic rocks, there appears to be a relative lack of intermediate types. 


\section{PETROGRAPHIC CLASSIFICATION}

Ever since his work on granites in the 1950s, Chayes had been interested in trying to improve the definition of petrographic names by using a quantitative approach. "In general, the only useful hypotheses are those which may be either confirmed or rejected by the observations they are created to explain, and to reach such hypotheses clear and unambiguous descriptive terminology is essential." 56 Thus he suggested (Chayes 1957) a method for the classification of granite based on criteria which could be obtained through modal analysis $\mathrm{s}^{57}$ and in Chayes (1966) he even argued for the abandonment of the term 'tholeiite'. It was not long before he was invited, in 1970, to join the International Union of Geological Sciences (IUGS) Subcommission on the Systematics of Igneous Rocks (1969-1989) under the chairmanship of the petrologist Albert L. Streckeisen (1901-1998), even though, on occasion, his views lay at odds with those of his Subcommission colleagues and could engender heated debate (e.g., the views expressed in Chayes 1981). ${ }^{58}$ Nevertheless, Chayes was an active participant in the committee discussions and in preparation of their total alkalis - silica (TAS) classification diagram (J. Brändle, pers. comm., 2004).$^{59}$ Chayes became Chair of the IUGS Subcommission on Electronic Databases for Petrology at the Geological Congress in Moscow in 1984.

With the advice of statisticians Cameron of the NBS, Calyampudi R. Rao (b. 1920), and Geoffrey Stuart Watson (1921-1998), ${ }^{60}$ Chayes (1965a, 1966), Chayes and Métais (1964), and Chayes and Velde (1965) were early users of discriminant analysis to obtain optimum linear or quadratic functions to distinguish between various lava suites and petrological types (e.g., basalt and andesite). However, as a result of later work which demonstrated the inherent variability of such procedures when using small sample sizes (Chayes 1987), he became somewhat disillusioned with the efficacy of classifications based on this approach. In related work, Trochimczyk and Chayes (1977) showed empirically that data for large numbers of representative samples are required before the estimates of principal components become reliable, independently confirming findings in the pattern-recognition literature that, for reliable results, the number of samples should be at least ten times the dimensionality of the number of variables (Howarth 1973).

In the late 1960s, interest in the origin of layered intrusions revived ${ }^{61}$ Chayes (1968, 1970b) and Bryan, Finger, and Chayes (1969) showed that least-squares mixing models could be used as a preferable alternative to graphical methods to estimate the composition of the unexposed 'hidden zone' of the Skaergaard igneous complex.

${ }^{56}$ Chayes, Replacement reactions, 1950, 22.

57 E. H. Timothy Whitten (personal communication, 2004) says that at Northwestern University this paper was used as an example of the difficulties inherent in partitioning a collection of analyses which happen to be available, or a set of samples chosen by others as typical representatives of rock units which they have named by experience.

58 See Young, Mind Over Magma, 2003, chap. 27 for discussion of the IUGS project.

59 See Young, Mind Over Magma, 2003, 537, 541.

${ }^{60}$ Felix Chayes and Danielle Velde, On distinguishing basaltic lavas of circumoceanic and oceanicisland type by means of discriminant functions, American Journal of Science, 1965, 263:206-222, cf. 220; Felix Chayes, A petrographic distinction between Cenozoic volcanics in and around the open oceans, Journal of Geophysical Research, 1964, 69:1573-1588, cf. 1585. Chayes's use of the NBS computing facilities had begun around 1960: Chayes, On correlation, 1960, 4193.

${ }^{61}$ See Young, Mind Over Magma, 2003, especially chaps. 17 and 29 for discussion of research on layered complexes. 


\section{CORRELATION IN 'CLOSED' DATA TABLES}

Chayes's (1948) early recognition of the problem posed by constant-sum data sets has already been mentioned, and he was aware that it insidiously influenced all the data on which petrologists relied-modal analyses, major element geochemistry, and the CIPW normative mineralogical compositions derived from the chemical composition. In another early paper (Chayes 1949a), he addressed the spurious correlation which can arise between common petrographic attributes (e.g., a plot of $\mathrm{K}_{2} \mathrm{O} /\left(\mathrm{K}_{2} \mathrm{O}+\mathrm{Na}_{2} \mathrm{O}\right)$ vs. $\mathrm{MgO} /(\mathrm{MgO}+\mathrm{FeO})$ and Niggli normative values). In the 1960 s Chayes, aided by discussion with Cameron and use of the NBS computing facilities, returned to the problem of induced correlation in closed data sets. In a series of papers (Chayes 1960, 1962a, 1964b), he tried to draw the attention of petrologists to the difficulty of interpreting apparent correlations between percentaged geochemical data, e.g., in the classic 'variation diagrams', in which major element oxide abundances were plotted as a function of increasing silica. He enlisted the help of statistician William H. Kruskal (b. 1919) to develop a test for the significance of such correlations (Chayes and Kruskal 1966, 1970). However, it later became apparent (Miesch 1969; Chayes 1970a; Kork 1977) that there were problems with the proposed test. In the winter of 1966, Chayes gave a course for geologists at Northwestern University on these new ideas and it was repeated at Harpur College, State University of New York, in the spring of $1967 . .^{62}$ This material formed the basis for his book Ratio Correlation (Chayes 1971a). Although favorably received by more numerate members of the geological community, it gradually became evident that the methods proposed were not really a satisfactory solution to the problem of closure. Even now, despite renewed interest, particularly among statisticians following the work of John Aitchison (b. 1926) (e.g., Aitchison 1982, 1986), a definitive answer remains elusive.

\section{DATA BASES FOR PETROLOGY}

As has been mentioned, Chayes began to compile a database of major-element analyses of Cenozoic volcanic rocks in 1961. By 1972, it comprised ca. 10,500 analyses, of which 7,600 were considered to be of 'superior' quality (Chayes and LeMaitre 1972) and grew to 16,000 analyses by 1976. In 1971, Chayes had begun to undertake data-retrieval requests using 'RKNFSYS' (an acronym for Rock Information System) for interested scientists in a pilot project funded by the National Science Foundation, ${ }^{63}$ but, by 1974, he and Brändle were seeking support for a larger-scale system (Chayes and Brändle 1974; Chayes 1990) which would include trace element and petrographic data. This was provided by the International Geological Correlation Programme Projects 163 (19771984; see Chayes (1985) for discussion) and 239 (1988-1990). These resulted in the development, under the auspices of the IUGS Commission for Systematics in Petrology Subcommission on Data Bases for Petrology (established in 1985 under Chayes's chairmanship) of new databases IGBADAT (Igneous Data Base) and SEDBA (Sedimentary Database) and their support software. Whereas RKNFSYS had been based essentially on retrospective datasets, these new projects aimed to include data being published in the contemporary literature, with a team of in-

${ }^{62}$ Felix Chayes, Ratio Correlation (Chicago: University of Chicago Press, 1971), cf. viii.

${ }^{63}$ E. H. Timothy Whitten (personal communication 2004) says that Chayes repeatedly, but in vain, tried to get Northwestern University to adopt RKNFSYS. It was resisted on the grounds that, while it might be useful to have a compliation of all the published analyses (e.g., of andesite), assembling what geologists chose as a representative sample of a rock formation, without full knowledge of how and why each particular sample was chosen for analysis, and how the analysis was made, etc., was contrary to all work in the department. 
ternational volunteers aiding data-capture. The work on the IGBA project dominated Chayes activities in the latter part of his career. However, he recognised all too clearly that

The major problem remains that data bases soon die if they are not continuously expanded and improved. Who will do the non-computational, non-executive, non-policy work of arranging and managing the periodic updating of IGBADAT? Where is this work to be done, and how will it be financed? ${ }^{64}$

Although nominally retired after 1986, Chayes continued to work a few days a week at the Geophysical Laboratory, programming and preparing data sheets for IGBA and he also became a research associate in the Department of Mineral Sciences at the National Museum of Natural History (Smithsonian Institution), Washington. Despite failing sight and a sudden loss of hearing, he continued working in his two offices, responding to enquiries, commenting on papers sent to him for review, and planning IGBA meetings. All this came to an end following a car accident sustained on 6 January 1993, not far from his home. In acute pain following the accident, he was recommended spinal surgery, as a preventive measure, with disastrous results: he became paralysed from the neck down and eventually died in hospital, from pneumonia, on 28 February, 1993. ${ }^{65}$

With the cessation of financial support following the ending of IGCP Project 239 in 1990, and Chayes's untimely death in 1993, the IGBA project was badly affected (Brändle and Nagy 1995). For historical reasons, the database (containing some 19,000 analyses) still mirrored its original 80-column format. As a result of restrictions imposed by the content and coding of the data records, its uneven geographical coverage, and incompleteness of some data records, it remained difficult to use for some studies. Nevertheless, a recent investigation (Torley and McBirney 2002) is hopeful that the situation can be remedied. If so, this would provide a lasting testament to Chayes's vision.

Chayes was awarded the ninth William Christian Krumbein Medal of the IAMG, its highest honour, at its 1984 symposium "Use and Abuse of Statistical Methods in the Earth Sciences" held in Reno, Nevada. He is commemorated by having the mineral chayesite, $\mathrm{K}\left(\mathrm{Mg}, \mathrm{Fe}^{2+}\right)_{4} \mathrm{Fe}_{3}{ }_{3} \mathrm{Si}_{12} \mathrm{O}_{30}$, a dark blue cyclosilicate from Moon Canyon, Summit County, Utah, named after him in 1989. The Felix Chayes Prize for Excellence in Research in Mathematical Petrology was established as a result of endowments by Dr. I. H. Chayes and Mrs. N. C. Tenney to the IAMG in 1996 and 1997. Fittingly, its first award was to the IUGS Subcommission on Data Bases for Petrology in 1997.

\section{ACKNOWLEDGMENTS}

I am extremely grateful to Irene H. Chayes and Natalie C. Tenney for providing me with much information about Felix Chayes's family background and life, and for clarification of some information in published sources; to Michael Le Bas for information and the loan of reprints; to José Brändle (Univ. Complutense, Madrid), Jeff Grossman (Geological Society of Washington), Shaun Hardy (Carnegie Institution), Pat Kilner (Geological Society of America), Michael Roberts (American Statistical Association), Alexander Speer (Mineralogical Society of America), and Timothy Whitten, for information; to Michael Connolly (American Geophysical Union) and Shaun Hardy (Carnegie Institution of Washington) for permission to reproduce illustrations; and to Irene Chayes, Michael Le Bas, Peter Sabine, and Timothy Whitten for comments on drafts of the manuscript.

\section{ARCHIVES}

Shaun J. Hardy, Librarian at the Carnegie Institution of Washington DTM-Geophysical Laboratory Library (5241 Broad Branch Road, N.W., Washington D.C. 20015; e-mail: hardy@dtm.ciw.edu)

\footnotetext{
${ }^{64}$ Felix Chayes, IGBADAT: A World data base for igneous petrology, Episodes, 1985, 8:245-251, on 251.

${ }^{65}$ I. H. Chayes (personal communication, 2004).
} 
informs me (pers. comm., 2004) that they hold a collection of seventeen boxes of Chayes's correspondence, publications, IGBA-related manuals and circulars, circulars from the IUGS Subcommittee on Igneous Rocks, data, slides, photographs and field notebooks, retrieved from his offices at the Laboratory and the Smithsonian shortly after his death. However, he cautions that "this material has not yet been appraised and processed, so it is difficult to say how much of it is valuable and worth retaining permanently."

\section{REFERENCES}

Aitchison, John, The statistical analysis of compositional data, Journal of the Royal Statistical Society, 1982, B44:139-177.

- The statistical analysis of compositional data (London: Chapman and Hall, 1986).

Bonnefoi, Catherine C., Ariel Provost, and Francis Albarède, The 'Daly gap' as a magmatic catastrophe, Nature, 1995, 378:270-272.

Brändle, José L., and Geza Nagy, The state of the 5th version of IGBA: Igneous petrological database, Computers \& Geosciences, 1995, 21:425-432.

Bryan, W. B., Larry W. Finger, and Felix Chayes, Estimating proportions in petrographic mixing equations by least-squares approximation, Science, 1969, 163:926-927.

Chayes, Felix, Geology of the alkaline and associated intrusive rocks of Bancroft, Ontario [abstract], Geological Society of America Bulletin, 1939a, 50:1904.

- Geology of the alkaline intrusives in the immediate vicinity of Bancroft, Hastings County, Ontario, MA Diss., Columbia University, Teachers College, New York, 1939b.

-, Alkaline and carbonate intrusives near Bancroft, Ontario, PhD Diss., Columbia University, Teachers College, New York, 1942a.

- Alkaline and carbonate intrusives near Bancroft, Ontario, Geological Society of America Bulletin, 1942b, 53:449-511.

- Petrographic analysis by fragment counting [Part 1, The counting error], Economic Geology, 1944a, 39:484-505.

— combined error of sampling and counting], Economic Geology, 1944b, 39:517-525.

- Application of the coefficient of correlation to fabric diagrams, Transactions of the American Geophysical Union, 1946a, 27:400-405.

- A correction factor for specific gravity and volume differences in fragment analysis, Economic Geology, 1946b, 41:749-760.

- Linear analysis of a medium-grained granite, American Mineralogist, 1946c, 31:261-275.

, A petrographic criterion for the possible replacement origin of rocks, American Journal of Science, 1948, 246:413-425.

, On ratio correlation in petrography, Journal of Geology, 1949a, 57:239-254.

- A simple point counter for thin-section analysis, American Mineralogist, 1949b, 34:1-11.

-, Some notes on the point counter, American Mineralogist, 1949c, 34:600-601.

- Statistical Analysis of Two-dimensional Fabric Diagrams, in H. W. Fairbairn, Structural Petrology of Deformed Rocks, 2 ed. (Cambridge, MA: Addison-Wesley, 1949d), 297-307.

- Statistical Analysis of Three-dimensional Fabric Diagrams, in H. W. Fairbairn, Structural Petrology of Deformed Rocks, 2 ed. (Cambridge, MA: Addison-Wesley, 1949e), 308-326.

, Composition of some New England granites, Transactions of the New York Academy of Sciences, 1950a, 12:144-151.

- On the bias of grain-size measurements made in thin section, Journal of Geology, 1950b, 58: $156-160$.

, On the relation between anorthite content and gamma-index of natural plagioclase, Journal of Geology, 1950c, 58:593-595.

$\longrightarrow$, Modal analyses of the granite and diabase test rocks, in A cooperative investigation of precision and accuracy in chemical, spectrochemical, and modal analysis of silicate rocks. Contributions to geochemistry 1950-1951, ed. Harold W. Fairbairn, U.S. Geological Survey Bulletin, 1951, 980:59-68. 254.

- Notes on the staining of potash feldspar with sodium cobaltinitrite in thin section, American Mineralogist, 1952b, 37:337-340.

- On the association of perthitic microcline with highly undulant or granular quartz in some calcalkaline granites, American Journal of Science, 1952c, 250:281-296. 
, Relations between composition and indices of refraction in natural plagioclase, American Journal of Science, 1952d, 250:85-105.

- The relation between area and volume in micrometric analysis, Mineralogical Magazine, 1953, 30:147-149.

, Effect of grain size on the efficiency of modal analysis of granitic rocks, Geological Society of America Bulletin, 1954a, 65:1238-1239.

, Potash feldspar as a by-product of the biotite-chlorite transformation, Transactions of the American Geophysical Union, 1954b, 35:377-378.

- A test of the revised determinative chart for plagioclase, American Journal of Science, 1954c, 252:172-180.

, The theory of thin section analysis, Journal of Geology, 1954d, 62:92-101.

, Modal composition of two facies of the Carnmenellis granite, Geological Magazine, 1955a, 92:364-366.

, Potash feldspar as a by-product of the biotite-chlorite transformation, Journal of Geology, $1955 \mathrm{~b}, 63: 75-82$.

, The Holmes effect and the lower limit of modal analysis, Mineralogical Magazine, 1956a, 31:276-281.

- Petrographic modal analysis. An elementary statistical appraisal (New York: Wiley, 1956b).

, A provisional reclassification of granite, Geological Magazine, 1957, 94:58-68.

, Diffraction effects of short-range ordering in layered sequences, in Researches in Geochemistry, ed. Philip H. Abelson (New York: Wiley, 1959), 359-376.

, On correlation between variables of constant sum, Journal of Geophysical Research, 1960, 65:4185-4193.

-, Numerical correlation and petrographic variation, Journal of Geology, 1962a, 70:440-452.

- On the relative scarcity of intermediate members in the oceanic basalt-trachyte association, Year Book, Carnegie Institution of Washington, 1962b, 61:121-123.

- Apparent relative scarcity of intermediate members in the oceanic basalt-trachyte association [abstract], Geological Society of America Special Publication,1963a, 73:128.

- A petrographic distinction between Cenozoic volcanics in and around the open oceans, Journal of Geophysical Research, 1964a, 69:1573-1588.

-, Variance-covariance relations in some published Harker diagrams of volcanic suites, Journal of Petrology, 1964b, 5:219-237.

, Classification in a ternary diagram by means of discriminant functions, American Mineralogist, 1965a, 50:1618-1633.

-, Statistical petrography, Year Book, Carnegie Institution of Washington, 1965b, 64:153-165.

- Alkaline and subalkaline basalts, American Journal of Science, 1966, 264:128-145.

- Statistical petrography, Year Book, Carnegie Institution of Washington, 1967, 66:372-379.

, A least squares approximation for estimating the amounts of petrographic partition products, Mineralogica et Petrographica Acta, 1968, 14:111-114.

- Effect of a single nonzero open covariance on the simple closure test, in Geostatistics: A colloquium, ed. Daniel F. Merriam (New York: Plenum Press, 1970a), 11-22.

, On estimating the magnitude of the hidden zone and the compositions of the residual liquids of the Skaergaard layered series, Journal of Petrology, 1970b, 11:1-14.

, Ratio correlation. A manual for students of petrology and geochemistry (Chicago: University of Chicago Press, 1971a).

, Statistical petrography, Year Book, Carnegie Institution of Washington, 1971b, 69:295-301.

, Silica saturation in Cenozoic basalt, Philosophical Transactions of the Royal Society, London, 1972, A271:285-296.

-, Statistical petrology, Year Book, Carnegie Institution of Washington, 1975, 74:542-550.

-, The oceanic basalt-trachyte relation in general and in the Canary Islands, American Mineralogist, 1977, 62:666-671.

- Distribution of basalt, basanite, andesite and dacite in a normative equivalent of the QAPF double triangle, Chemical Geology, 1981, 33:127-140.

, IGBADAT; a world data base for igneous petrology, Episodes, 1985, 8:245-251.

, Consistency of the two-group discriminant function in repartitioning rocks by name, in Use and Abuse of Statistical Methods in the Earth Sciences, ed. William B. Size (New York: Oxford University Press, 1987), 47-54.

- Notes on the prehistory and early history of digitized data bases and related information systems in igneous petrology, Episodes, 1990, 13:18-21. 
Chayes, Felix, and José L. Brändle, Feasibility Study for a Publicly Accessible Rock Information System, Geophysical Laboratory; Systematic petrology, Year Book, Carnegie Institution of Washington, 1974, 480-488.

Chayes, Felix, and Harold W. Fairbairn, A test of the precision of thin-section analysis by point counter, American Mineralogist, 1951, 36:704-712.

Chayes, Felix, and William Kruskal, An approximate statistical test for correlations between proportions, Journal of Geology, 1966, 74:692-702.

Chayes, Felix, and William Kruskal, An approximate statistical test for correlations between proportions: Some corrections, Journal of Geology, 1970, 78:380.

Chayes, Felix, and Roger W. LeMaitre, Published Analyses of Igneous Rocks, Nature, 1972, 236: 449-450.

Chayes, Felix, and D. Métais, On distinguishing basaltic lavas of intra- and circumoceanic types by means of discriminant functions, Transactions of the American Geophysical Union, 1964, 45: 124.

Chayes, Felix, and Danielle Velde, On distinguishing basaltic lavas of circum-oceanic and oceanicisland type by means of discriminant functions, American Journal of Science, 1965, 263:206222.

Fairbairn, Harold W., ed., A cooperative investigation of precision and accuracy in chemical, spectrochemical, and modal analysis of silicate rocks. Contributions to geochemistry 1950-51, U.S. Geological Survey Bulletin, 1951, 980:1-71.

Howarth, Richard J., The pattern recognition problem in applied geochemistry, in Geochemical Exploration 1972, ed. Michael J. Jones (London: Institute of Mining and Metallurgy, 1973), 259273.

Keith, Mackenzie L., Selective staining to facilitate Rosiwal analysis, American Mineralogist, 1939, 24, 561-571.

Kork, John O., Examination of the Chayes-Kruskal procedure for testing correlations between proportions, Mathematical Geology, 1977, 9:543-562.

Miesch, Alfred T., The constant sum problem in geochemistry, in Computer Applications in the Earth Sciences, ed. Daniel F. Merriam (New York: Plenum Press, 1969), 161-176.

Robbins, Carl R., and Felix Chayes, Compositions of feldspars in some two-feldspar granites, Geological Society of America Bulletin, 1956, 67:1727-1728.

Rosiwal, August K., Ueber geometriche Gesteinsanalysen. Ein einfacher Weg zur ziffernmässigen Festellung des Quantitätsverhältnisses der Mineralbestandtheile egmengter Gesteine, Verhandlung der Kaiserlich-Königslich geologischen Reichsanstalt, 1898, 5:143-175.

Shand, Samuel J., Eruptive Rocks. Their genesis, composition, classification and their relation to ore deposits with a chapter on meteorites (New York: Wiley, 1927).

Snedecor, George W., Statistical methods, 4 ed. (Ames, Iowa: Iowa State College Press, 1946).

Suzuki, Y., and Felix Chayes, Estimating the composition of zoned plagioclase, Year Book, Carnegie Institution of Washington, 1961, 60:169-172.

Torley, Roy, and Alexander McBirney, Potentialities of a neglected igneous database IGBADAT5, Natural Resources Research, 2002, 11:71-75.

Trochimczyk, Jurgen, and Felix Chayes, Sampling variation of principal components, Mathematical Geology, 1977, 9:497-506.

Washington, Henry S., Manual of the Chemical Analysis of Rocks, 3 ed. (New York: Wiley, 1919).

Wentworth, Chester J., An improved recording micrometer for rock analysis, Journal of Geology, 1923, 31:228-232.

Yule, George U., and Maurice Kendall, An Introduction to the Theory of Statistics, 13 ed. (London: Griffin, 1946). 